\title{
Analytical Hierarchy Process (AHP), Fuzzy AHP, and TOPSIS for Determining Bridge Maintenance Priority Scale in Banjarsari, Surakarta
}

\author{
Ayu Intan Nurani ${ }^{1}$, Astri Tamara Pramudyaningrum ${ }^{2}$, Shofie Rizqi Fadhila ${ }^{3}$, \\ Senot Sangadji ${ }^{4}$, Widi Hartono ${ }^{5}$ \\ Civil Engineering Program Sebelas Maret University, \\ J1. Ir. Sutami 36A Kentingan Jebres Surakarta 57126, INDONESIA \\ ayuintannurani@gmail.com
}

\begin{abstract}
Data on 2015 [9] show that less than 50 percent of provincial and local level bridges in Central Java are in good condition. In the other hand, it has been reported that local bridges in the city of Surakarta have been deteriorated and damaged. The maintenance and rehabilitation action often done based solely on incidental reports without systematic planning. Analytical Hierarchy Process, Fuzzy Analytical Hierarchy Process, and Technique for Order Preference by Similarity to Ideal Solution (TOPSIS) were used to compare the priority scale of bridge management in Kecamatan (District) Banjarsari, Surakarta. Bridge Management System 1993 (BMS 1993) standard was used to quantify bridge damage condition by means of direct visual observation. Scores used in this 3 different analysis were determined by comparing aforementioned 2 criteria and 9 sub criteria. Accordingly, criteria and subcriteria defined in this paper were based on the standard. The criteria employed were bridge damage condition and average daily traffic (ADT). Bridge condition criteria were then divided further into sub criteria; i.e. river stream, safety support building, foundation, pier, girder system, parapet, floor system, expansion joint, and other property. From 11 bridges considered in this study, Maris Bridge has the highest pirority determined in 3 different methods. AHP and TOPSIS methods show Ringin Semar Bridge the lowest priority to maintain. On the other hand, Fuzzy AHP determines Balapan Bridge as the lowest order. Keyword: Bridge Management, BMS 1993, AHP, FAHP, TOPSIS.
\end{abstract}

\section{Introduction}

Bridge examination and maintenance is a process of Bridge Management System which includes routine maintenance intervals to give a better monitoring system and control maintenance. Data on 2015 [9] show that less than 50 percent of provincial and local level bridges in Central Java are in good condition. In the other hand, it has been reported that local bridges in the city of Surakarta have been deteriorated and damaged. Yet, there is no effective and efficient maintenance program handling the problem.

The condition limit of the bridge can be exceeded early due to damage of main elements. Unplanned and insindental maintenance has the potential to disrupt the flow of traffic and significantly increase the cost of road users. By studying the method of bridge management for the assessment of the condition of the bridge it is expected to assist in developing a good bridge management system. [13]. The maintenance and rehabilitation action in Surakarta often done based solely on incidental reports without 
systematic planning. Further, data inaccuracies make the bridge maintenance at local level even ineffective without appropriate resources allocation. The government of the city of Surakarta was fully aware of the problem and needs decision making support system for systematic and rational maintenance and rehabilitation program of local bridges. Maintenance done be gave a hope that all the in Indonesia will be effective and the purpose of an examination this Bridge was to convince that bridges are working safely and the need for held a certain action to the maintenance and repair of periodically of maintenance in bridge any very important to therefore condition bridge is staying on its function [5].

This study investigates condition assessment on 11 bridges in Banjarsari, owned by Surakarta City Government as starting point to set priority for their efficient maintenance. Condition assessment was performed by means of the Bridge Management System (BMS) standard while priority analysis utilized the Analytical Hierarchy Process (AHP) method, fuzzy logic (Fuzzy AHP), and TOPSIS.

Bridge Management System 1993 (BMS 1993) standard was used to quantify bridge damage condition by means of direct visual observation. Accordingly, criteria and subcriteria defined in this paper were based on the standard. In this study, only comparisons of priority scale compilations between AHP, Fuzzy AHP, and TOPSIS were then compared

\section{Methodology}

\subsection{Research Object}

There are 11 bridges chosen in Banjarsari, Surakarta for analysis. These bridges were recapitulated in table 1 .

Table 1. Bridges List

\begin{tabular}{cll}
\hline No. & \multicolumn{1}{c}{ Street } & \multicolumn{1}{c}{ Bridge Name } \\
\hline $\mathbf{1}$ & Jl. Walanda Maramis & Maris \\
$\mathbf{2}$ & Jl. Adi Sumarmo & Komplang \\
$\mathbf{3}$ & Jl. Letjen S. Parman & Pasar Legi \\
$\mathbf{4}$ & Jl. Monginsidi & Ringin Semar \\
$\mathbf{5}$ & Jl. Sutan Syahrir & Ngebrusan \\
$\mathbf{6}$ & Jl. Letjen Sutoyo & Ngemplak \\
$\mathbf{7}$ & Jl. Kusumoyudan & Setabelan \\
$\mathbf{8}$ & Jl. D.I. Panjaitan & Rejosari \\
$\mathbf{9}$ & Jl. Dr. Setia Budi & Munggung \\
$\mathbf{1 0}$ & Jl. Gadjah Mada & Balapan \\
$\mathbf{1 1}$ & Jl. Letjen Sutoyo & Nayu Ngemplak \\
\hline
\end{tabular}

\subsection{Data Collection}

Primary data is data obtained from direct observation from the field. In this study, primary data consists of two types: primary data for analysis with BMS method and data for analysis of AHP and FAHP methods. Primary data for BMS analysis were obtained from the assessment of the condition of bridge elements and components visually in the study sites. Assessment refers to the bridge inspection form based on BMS standards. 
For analysis, AHP and FAHP method required data from purposive questionnaires given to respondents. Target respondents are stakeholders who have work experience in the field of bridge maintenance. The respondents were ten officers and engineers from the Department of Public Works Surakarta and the Technical Executing Agency of Bina Marga Surakarta. Scores given by respondents are recapitulated on table 2.

Secondary data is supporting data obtained from an intermediate medium or reference. These data were obtained from Public Works Department of Central Java Province, namely road map and daily traffic data report. Saaty (2008) assigns a quantitative scale of 1 (one) to 9 (nine) to assess the comparative importance of an element to another.

Tabl 2. Scale of Relatives Importances [12]

\begin{tabular}{cc}
\hline Importance Scale & Definition \\
\hline 1 & Equal importance \\
3 & Weak importance of one over another \\
5 & Essential or strong importance \\
7 & Demonstrated importance \\
9 & Absolute importance \\
$2,4,6,8$ & Intermediate values between two adjacent judgments \\
Reciprocals & when compared with activity $\mathrm{j}$, then $\mathrm{j}$ has the reciprocal value when \\
& compared with i. \\
\hline
\end{tabular}

\subsection{Hierarchy Structure}

Criteria and subcriteria defined in this paper were based on BMS 1993 standard. The criteria employed were bridge damage condition (A) and average daily traffic (ADT) (B). Bridge condition criteria were then divided further into sub criteria; i.e. river stream (A1), safety support building (A2), foundation (A3), pier (A4), girder system (A5), parapet (A6), floor system (A7), expansion joint (A8), and other property (A9). The hierarchy structure consists of criteria and subcriteria of this problem is shown in Figure 1. 


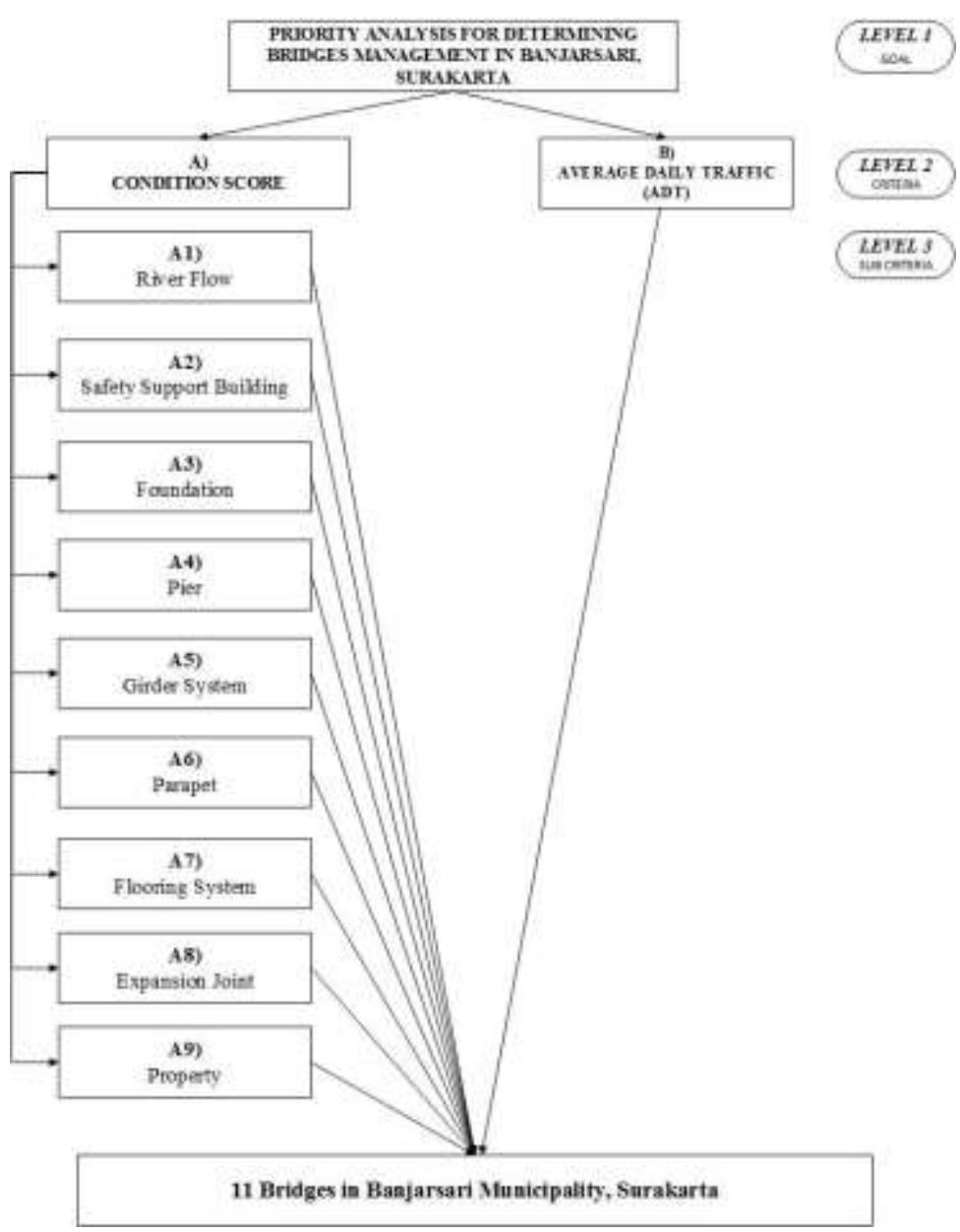

Figure 1. Hierarchial Structure of The Problem

\subsection{Analytical Hierarchy Process (AHP)}

AHP is a model developed by Thomas 1.Saaty.Supporting model decision that disassemble problems multi-factors or multi the criteria a complex into a hierarchy [9]. Analytical Hierarchy Process had the capability for solving a problem that multiply the criteria based on a comparison preference of an element in the hierarchy [5]. Comparisons scores that were given by respondents should be constructed as a set of pairwise comparison matrix. Comparison matrix from both criteria and subcriteria were analyzed to determine priority weight of each element. Consistency ratio should be checked for every elements in each bridges. Analytical Hierarchy Process according to Saaty are explained as follows.

2.4.1. Matrix pairwise comparison. Comparison value of element $\mathrm{A}_{1}$ to $\mathrm{A}_{2}$ is $\mathrm{a}_{12}$. It is determined by:

a) If $\mathrm{a}_{\mathrm{nm}}=\alpha$, then $\mathrm{a}_{\mathrm{nm}}=1 / \alpha, \alpha \neq 0$

b) If "An" seem to have the same level of importance with Am, then anm $=a m n=1$. The value of "a" was given by respondents. Since there are more than 1 respondent then geometric mean was used to normalize opinions. Geometric mean (GM) can be determined by equation (1) 
$\mathrm{GM}=$ Geo Mean, $\mathrm{n}=$ number of respondents, $\mathrm{x}_{\mathrm{n}}=$ scoring by respondent $\mathrm{n}$.

2.4.2. Determining eigenvector. Eigenvector was used to make a priority rank between elements in comparison matrices. Eigenvector was obtained by doing these steps:

a) Squaring the matrix until there is no difference in eigenvector value between source matrix and the squared matrix.

b) Sum up values in a row of the squared matrix to get PV.

$$
P V=a_{11}+a_{12}+\cdots+a_{1 n}
$$

$\mathrm{PV}=$ sum of row, $\mathrm{a}_{\mathrm{ij}}=$ matrix value row $\mathrm{i}$, column $\mathrm{j}$.

c) The eigenvector is determined by equation (3).

$$
W p=\frac{P V}{\sum P V}
$$

$\mathrm{Wp}=$ eigenvector, $\mathrm{PV}=$ sum of row,$\Sigma \mathrm{PV}=$ sum of $\mathrm{PV}$ in a column

2.4.3. Determining eigen maximum $\left(\lambda_{\max }\right)$. Eigen maximum is determined by multiply comparison matrix with eigenvector earned before.

$$
\lambda_{\text {maks }}=\sum a_{i j} \times W p
$$

$\lambda_{\max }=$ eigen maximum, $a_{\mathrm{ij}}=$ matrix value row $\mathrm{i}$, column $\mathrm{j}$., $\mathrm{W}_{\mathrm{p}}=$ eigenvector

2.4.4. Validation. Validation is needed for knowing the consistency of opinions given by respondents. The consistency will be affect to the result. Validation is determined by the consistency ratio (CR). If $\mathrm{CR}>10 \%$, then judgment value should be fixed. These following points is the procedure to get consistency ratio.

a) Determine consistency index (CI).

$$
C I=\frac{\lambda_{m a k s}-n}{n-1}
$$

$\mathrm{CI}=$ Consistency Index, $\lambda \max =$ eigen maximum, $\mathrm{n}=$ order of matrix

b) Determine the random index (RI) according to order of the matrix. Random indexes were listed as follow:

Tabel 3. Random index (Saaty 1998, in Nurdin 2016)

\begin{tabular}{c|c|c|c|c|c|c|c|c|c|c}
\hline $\boldsymbol{n}$ & 1 & 2 & 3 & 4 & 5 & 6 & 7 & 8 & 9 & 10 \\
\hline $\boldsymbol{R I}$ & 0 & 0 & 0,58 & 0,9 & 1,12 & 1,24 & 1,32 & 1,41 & 1,45 & 1,49 \\
\hline
\end{tabular}

c) Determine the consistency ratio with equation (6).

$$
C R=\frac{C I}{R I}
$$

$\mathrm{CR}=$ Consistency Ratio, CI $=$ Consistency Index, $\mathrm{RI}=$ Random Index.

\section{5. $F A H P$}

Fuzzy AHP is the combination of AHP method using fuzzy concept approach. To determine the value of fuzzy AHP, it used Triangular Fuzzy Number (TFN). Triangular Fuzzy Number (TFN) is fuzzy association theory related with subjective human assessment using linguistics. Bridge priority maintenance determination in Surakarta 
was conducted by calculating the condition number of each bridge based on the selected criteria.

2.5.1. Scale assessment conversion. Change the weight from AHP scale to fuzzy number using TFN as shown in the table I. TFN was indicated by value $1, \mathrm{~m}$, $\mathrm{u}$ which describe smallest possibility, that promising the biggest possibility.

Table 4. Scale Assessment Conversion Fuzzy AHP

\begin{tabular}{lccc}
\hline \multicolumn{1}{c}{$\begin{array}{c}\text { Linguistic Scale For } \\
\text { Importance }\end{array}$} & Fuzzy Numbers & Triangular Fuzzy Number (TFN) & Reciprocal \\
\hline Just Equal & 1 & $(1,1,3)$ & $(1 / 3,1,1)$ \\
Moderatesly important & 3 & $(1,3,5)$ & $(1 / 5,1 / 3,1)$ \\
Strongly Important & 5 & $(3,5,7)$ & $(1 / 7,1 / 5,1 / 3)$ \\
Very strong & 7 & $(5,7,9)$ & $(1 / 9,1 / 7,1 / 5)$ \\
Extremely strong & 9 & $(7,9,9)$ & $(1 / 9,1 / 9,1 / 7)$ \\
\hline
\end{tabular}

\subsubsection{Determine Fuzzy Synthetic Extent (Si) number}

$$
S i=\Sigma_{j=1}^{m} M_{g i}^{j} x\left[\Sigma_{i=1}^{n} \Sigma_{j=1}^{m} M_{g i}^{j}\right]^{-1}
$$

$\mathrm{Si}=$ fuzzy synthetic number, $\Sigma \_(\mathrm{j}=1)^{\wedge} \mathrm{m} \mathrm{M}_{-} \mathrm{gi}^{\wedge} \mathrm{j}=$ total number of cells in the column that started from column 1 in every matrix row, $\mathrm{j}=$ column, $\mathrm{i}=$ row, $\mathrm{M}=$ Triangular Fuzzy Number $(\mathrm{TFN}), \quad \mathrm{m}=$ total of the criteria, $\mathrm{g}=$ parameter $(1, \mathrm{~m}, \mathrm{u})$

\subsubsection{Calculating Degree of Possibility (V)}

$$
V\left(M_{1} \geq M_{2}\right)=\left\{\begin{array}{cc}
1 ; & \text { jika } m_{1} \geq m_{2} \\
0 ; & \text { jika } l_{2} \geq u_{1} \\
\frac{l_{1}-u_{2}}{\left(m_{2}-u_{2}\right)-\left(m_{1}-l_{1}\right)} & \text { sebaliknya }
\end{array}\right.
$$

2.5.4. Comparing the degree of possibility between the criteria. This step was done by taking the smallest number in degree of possibility in each criteria.

$$
W^{\prime}=\left(d '(A), d{ }^{\prime}(B), \ldots \ldots . ., d^{\prime}(A n)\right) T
$$

2.5.5. Vector weight normalization. Vector weight normalization was done using equation as follows:

$$
\operatorname{CRISP} d\left(A_{n}\right)=\frac{d^{\prime}(A n)}{\sum_{i}^{n} d^{\prime}(A n)}
$$

$d^{\prime}=$ value of crisp for An criteria, $d^{\prime}(A n)=$ the minimum value from degree of possibility for a criteria

\subsection{Technique for Order Preference by Similiarity to Ideal Solution (TOPSIS)}

TOPSIS is one of multicritedia troubleshooting method that giving the solution of alternatives by comparing the best alternatives and the worst alternatives[8]. Steps of TOPSIS: 


\subsubsection{Create a decision matrix.}

$$
X=a_{3}\left[\begin{array}{ccccc}
a_{1} \\
a_{2} \\
\vdots \\
a_{m}
\end{array}\left[\begin{array}{ccccc}
x_{1} & x_{2} & x_{3} & \ldots & x_{n} \\
x_{11} & x_{12} & x_{13} & \ldots & x_{1 n} \\
x_{21} & x_{22} & x_{23} & \ldots & x_{2 n} \\
x_{31} & x_{32} & x_{33} & \ldots & x_{3 n} \\
\vdots & \vdots & \vdots & & \vdots \\
x_{m 1} & x_{m 2} & x_{m 3} & \ldots & x_{m n}
\end{array}\right]\right.
$$

2.6.2. Create a normalized decision matrix

$$
r_{i j}=\frac{x_{i j}}{\sqrt{\sum_{i=1}^{m} x_{i j}^{2}}}
$$

2.6.3. Determine positive ideal solution matrix and negative ideal solution matrix. Positive ideal solution matrix is the maximum value for each criterion from all alternatives, on the other hand negative ideal solution is the minimum value for each criterion from all alternatives.

2.6.4. Calculate separation measure. Separation measure is a measurement of distance from an alternative by using a positive ideal solution and negative ideal solution.

$$
\begin{aligned}
& D_{i}^{+}=\sqrt{\sum_{i=1}^{n}\left(Y_{i j}-Y_{j}^{+}\right)^{2}} \\
& D_{i}^{-}=\sqrt{\sum_{i=1}^{n}\left(Y_{i j}-Y_{j}^{-}\right)^{2}}
\end{aligned}
$$

2.6.5. Calculate the preference value for each alternatives

$$
V_{i}^{+}=\frac{D_{i}^{-}}{\left(D_{i}^{+}+D_{i}^{-}\right)}, 0 \leq V_{i}^{+} \leq 1
$$

2.6.6. Rank the alternatives. The alternatives be sorted from the greatest $\mathrm{V}$ to the samllest V.

\section{Results and Discussion}

The number of respondents who gave the assessment was ten people, so the weight of group assessment is stated by looking for the geometric mean value (Geometric Mean) of the assessment given by all respondents. This geometric mean value is then compiled into a comparison matrix and a weighted analysis is performed between criteria.

Tabel 5. Matrix Comparison (Criteria)

\begin{tabular}{ccc}
\hline & $\begin{array}{c}\text { Bridge } \\
\text { Condition }\end{array}$ & $\begin{array}{c}\text { Average Daily } \\
\text { Traffic (ADT) }\end{array}$ \\
\hline Bridge Condition & 1 & 4,9294 \\
\hline Average Daily Traffic (ADT) & 0,2029 & 1 \\
\hline
\end{tabular}

Tabel 6. Matriks Comparison (Subcriteria)

\begin{tabular}{cccccccccc}
\hline & $\mathbf{A 1}$ & $\mathbf{A 2}$ & $\mathbf{A 3}$ & $\mathbf{A 4}$ & $\mathbf{A 5}$ & $\mathbf{A 6}$ & $\mathbf{A 7}$ & $\mathbf{A 8}$ & $\mathbf{A 9}$ \\
\hline $\mathbf{A 1}$ & 1,0000 & 0,7762 & 0,3066 & 0,8960 & 0,3786 & 0,7947 & 0,5966 & 0,5870 & 0,9368 \\
$\mathbf{A 2}$ & 1,2884 & 1,0000 & 0,1418 & 0,2389 & 0,3060 & 0,3309 & 0,3205 & 0,4275 & 2,3618 \\
$\mathbf{A 3}$ & 3,2612 & 7,0511 & 1,0000 & 3,6224 & 4,7220 & 2,8587 & 4,8264 & 3,0963 & 5,4929 \\
$\mathbf{A 4}$ & 1,1161 & 4,1864 & 0,2761 & 1,0000 & 2,1594 & 2,1823 & 1,7335 & 1,8616 & 2,7855
\end{tabular}




\begin{tabular}{cccccccccc}
\hline & $\mathbf{A 1}$ & $\mathbf{A 2}$ & $\mathbf{A 3}$ & $\mathbf{A 4}$ & $\mathbf{A 5}$ & $\mathbf{A 6}$ & $\mathbf{A 7}$ & $\mathbf{A 8}$ & $\mathbf{A 9}$ \\
\hline $\mathbf{A 5}$ & 2,6415 & 3,2679 & 0,2118 & 0,4631 & 1,0000 & 4,3970 & 2,9113 & 2,8276 & 4,4218 \\
$\mathbf{A 6}$ & 1,2584 & 3,0219 & 0,3498 & 0,4582 & 0,2274 & 1,0000 & 0,3007 & 0,5899 & 3,5641 \\
$\mathbf{A 7}$ & 1,6761 & 3,1203 & 0,2072 & 0,5769 & 0,3435 & 3,3254 & 1,0000 & 3,3866 & 4,1964 \\
$\mathbf{A 8}$ & 1,7035 & 2,3389 & 0,3230 & 0,5372 & 0,3537 & 1,6952 & 0,2953 & 1,0000 & 4,8401 \\
$\mathbf{A 9}$ & 1,0674 & 0,4234 & 0,1821 & 0,3590 & 0,2262 & 0,2806 & 0,2383 & 0,2066 & 1,0000 \\
\hline
\end{tabular}

\subsection{AHP Result}

The comparison criterion matrix is order 2, therefore there is no need for consistency test. While the result of consistency matrix test of comparative subcriteria evaluation showed that the data is consistent because the consistency ratio equal to 0,0876 so that fulfill the criterion of consistency ratio $<0,1$. The result of consistency test of subcriteria assessment is shown in table 7 . The result of recapitulation of criterion weight and subcriteria with AHP method is described in table 8. The result of weighting is then multiplied by the quantity value of each criterion and subcriterion element on each bridge.

Tabel 7. Data Validation (Subcriteria)

\begin{tabular}{ccc}
\hline $\mathbf{n}=\mathbf{9}$ & Consistency Test & \\
& $\mathrm{RI}=1,45$ & $\mathrm{CI}=0,127$ \\
$\mathbf{C R}=\mathbf{0 , 0 8 7 6}$ & \\
$\mathrm{CR}<\mathbf{0 , 1} \rightarrow$ Valid &
\end{tabular}

Tabel 8. Criteria and Subcriteria Weight (AHP)

\begin{tabular}{|c|c|c|c|c|c|}
\hline & Criteria & Weight & & Sub criteria & Weight \\
\hline \multirow[t]{9}{*}{$\mathbf{A}$} & Bridge Condition & 0,8313 & A1 & River flow & 0,0564 \\
\hline & & & A2 & Safety Support Building & 0,0405 \\
\hline & & & A3 & Fondation & 0,3178 \\
\hline & & & A4 & Pier & 0,1371 \\
\hline & & & A5 & Girder System & 0,1556 \\
\hline & & & A6 & Parapet & 0,0661 \\
\hline & & & A7 & Floor System & 0,1154 \\
\hline & & & $\mathbf{A 8}$ & Expansion Joint & 0,0798 \\
\hline & & & A9 & Other Property & 0,0313 \\
\hline B & $\begin{array}{l}\text { Average Daily } \\
\text { Traffic (ADT) }\end{array}$ & 0,1687 & & & \\
\hline
\end{tabular}

\subsection{FAHP Result}

Based on data from respondents about the comparison of the bridge's elements, the conversion results from AHP scale to fuzzy number using TFN as shown in table 9 and 10.

Table 9. The conversion results of criteria

\begin{tabular}{ccccccc}
\hline \multirow{2}{*}{ CRITERIA } & \multicolumn{3}{c}{$\mathbf{A}$} & $\mathbf{3}$ & $\mathbf{B}$ & $\mathbf{M}$ \\
\cline { 2 - 7 } & $\mathbf{L}$ & $\mathbf{M}$ & $\mathbf{U}$ & $\mathbf{L}$ & $\mathbf{M}$ & $\mathbf{U}$ \\
\hline $\mathbf{A}$ & 1 & 1 & 1 & 3,5068 & 4,9294 & 6,3124 \\
$\mathbf{B}$ & 0,1584 & 0,2029 & 0,2852 & 1 & 1 & 1 \\
\hline
\end{tabular}


Table 10. The conversion results of sub criteria

\begin{tabular}{|c|c|c|c|c|c|c|c|c|c|c|}
\hline \multicolumn{2}{|c|}{ SUBCRITERIA } & A1 & A2 & $\mathbf{A 3}$ & A4 & A5 & A6 & A7 & A8 & A9 \\
\hline \multirow{3}{*}{ A1 } & $\mathbf{L}$ & 1 & 0,6557 & 1,6870 & 0,5133 & 1,3865 & 0,6801 & 0,8891 & 0,9349 & 0,6594 \\
\hline & $\mathbf{M}$ & 1 & 1,2884 & 2,8391 & 1,1161 & 2,6415 & 1,0955 & 1,6761 & 1,7035 & 0,9292 \\
\hline & $\mathbf{U}$ & 1 & 1,8549 & 4,4288 & 1,3211 & 3,9363 & 2,0377 & 2,2144 & 2,6011 & 1,6896 \\
\hline \multirow{3}{*}{ A2 } & $\mathbf{L}$ & 0,5391 & 1 & 4,7858 & 2,4278 & 1,5804 & 1,5072 & 1,5188 & 1,2173 & 0,2826 \\
\hline & $\mathbf{M}$ & 0,7762 & 1 & 7,0511 & 4,1864 & 3,2679 & 3,0219 & 2,7163 & 2,3389 & 0,4234 \\
\hline & $\mathbf{U}$ & 1,5250 & 1 & 8,2756 & 4,5471 & 4,0365 & 3,4461 & 4,2255 & 2,9818 & 0,6815 \\
\hline \multirow{3}{*}{$\mathbf{A} 3$} & $\mathbf{L}$ & 0,2258 & 0,1208 & 1 & 0,1701 & 0,1497 & 0,1997 & 0,1472 & 0,1933 & 0,1374 \\
\hline & $\mathbf{M}$ & 0,3522 & 0,1418 & 1 & 0,2761 & 0,2118 & 0,3498 & 0,2072 & 0,3230 & 0,1821 \\
\hline & $\mathbf{U}$ & 0,5928 & 0,2090 & 1 & 0,5253 & 0,3224 & 0,6608 & 0,3936 & 0,7192 & 0,2763 \\
\hline \multirow{3}{*}{ A4 } & $\mathbf{L}$ & 0,7569 & 0,2199 & 1,9037 & 1 & 0,2580 & 0,2866 & 0,2814 & 0,2724 & 0,2182 \\
\hline & M & 0,8960 & 0,2389 & 3,6224 & 1 & 0,4631 & 0,4582 & 0,5769 & 0,5372 & 0,3590 \\
\hline & $\mathbf{U}$ & 1,9481 & 0,4119 & 5,8776 & 1 & 0,6960 & 0,7591 & 0,7068 & 0,8027 & 0,5304 \\
\hline \multirow{3}{*}{ A5 } & $\mathbf{L}$ & 0,2540 & 0,2477 & 3,1013 & 1,4368 & 1 & 0,1504 & 0,2036 & 0,2064 & 0,1563 \\
\hline & M & 0,3786 & 0,3060 & 4,7220 & 2,1594 & 1 & 0,2274 & 0,3435 & 0,3537 & 0,2262 \\
\hline & $\mathbf{U}$ & 0,7213 & 0,6327 & 6,6779 & 3,8761 & 1 & 0,3778 & 0,5404 & 0,6123 & 0,4653 \\
\hline \multirow{3}{*}{ A6 } & $\mathbf{L}$ & 0,4907 & 0,2902 & 1,5133 & 1,3174 & 2,6468 & 1 & 1,7625 & 0,9117 & 0,1965 \\
\hline & M & 0,9129 & 0,3309 & 2,8587 & 2,1823 & 4,3970 & 1 & 3,3254 & 1,4758 & 0,2806 \\
\hline & $\mathbf{U}$ & 1,4704 & 0,6635 & 5,0080 & 3,4898 & 6,6486 & 1 & 4,9076 & 2,4875 & 0,4670 \\
\hline \multirow{3}{*}{ A7 } & $\mathbf{L}$ & 0,4516 & 0,2367 & 2,5405 & 1,4148 & 1,8503 & 0,2038 & 1 & 0,1775 & 0,1598 \\
\hline & M & 0,5966 & 0,3681 & 4,8264 & 1,7335 & 2,9113 & 0,3007 & 1 & 0,2953 & 0,2383 \\
\hline & $\mathbf{U}$ & 1,1247 & 0,6584 & 6,7954 & 3,5540 & 4,9113 & 0,5674 & 1 & 0,4789 & 0,4921 \\
\hline \multirow{3}{*}{ A8 } & $\mathbf{L}$ & 0,3845 & 0,3354 & 1,3904 & 1,2457 & 1,6332 & 0,4020 & 2,0880 & 1 & 0,1461 \\
\hline & $\mathbf{M}$ & 0,5870 & 0,4275 & 3,0963 & 1,8616 & 2,8276 & 0,6776 & 3,3866 & 1 & 0,2066 \\
\hline & $\mathbf{U}$ & 1,0696 & 0,8215 & 5,1729 & 3,6710 & 4,8440 & 1,0968 & 5,6327 & 1 & 0,3643 \\
\hline \multirow{3}{*}{ A9 } & $\mathbf{L}$ & 0,6594 & 1,4674 & 3,6195 & 1,8852 & 2,1489 & 2,1411 & 2,0320 & 2,7451 & 1 \\
\hline & M & 0,9292 & 2,3618 & 5,4929 & 2,7855 & 4,4218 & 3,5641 & 4,1964 & 4,8401 & 1 \\
\hline & $\mathbf{U}$ & 1,6896 & 3,5380 & 7,2774 & 4,5826 & 6,3974 & 5,0898 & 6,2562 & 6,8427 & 1 \\
\hline
\end{tabular}

The result data of criteria and subcriteria based on FAHP method as shown in table 11 and 12 .

Table 11. Criteria and subcriteria weight (FAHP)

\begin{tabular}{|c|c|c|c|c|c|}
\hline & Criteria & Weight & & Subcriteria & Weight \\
\hline \multirow[t]{6}{*}{ A } & Bridge Condition & 1 & A1 & River flow & 0,0279 \\
\hline & & & A2 & Safety Support Building & 0,0110 \\
\hline & & & A3 & Fondation & 0,2646 \\
\hline & & & A4 & Pier & 0,1603 \\
\hline & & & A5 & Girder System & 0,1952 \\
\hline & & & A6 & Parapet & 0,0743 \\
\hline
\end{tabular}




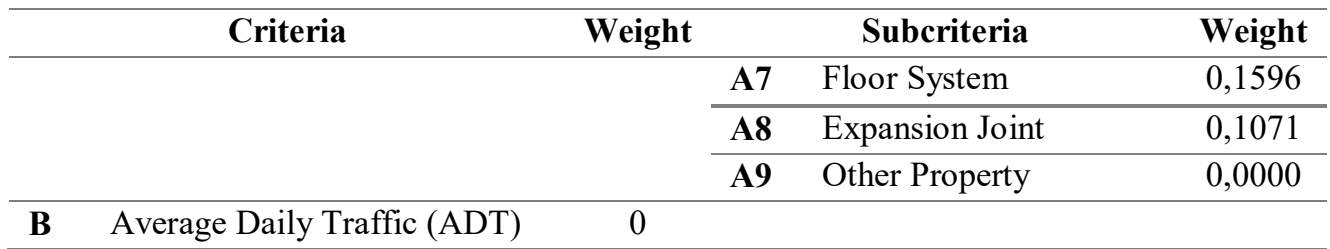

\subsection{TOPSIS Result}

Pair comparison matrix is obtained from the result of the questionnaire given to the stakeholder for resulting the criteria-weight dan subcriteria-weight. With TOPSIS method, pair comparison matrix is analyzed for the consistency and the result is 0,0885 .

Table 12. Criteria and subcriteria weight (TOPSIS)

\begin{tabular}{|c|c|c|c|c|c|}
\hline \multirow{2}{*}{\multicolumn{2}{|c|}{$\begin{array}{rr} & \text { Criteria } \\
\text { A } \quad \text { Bridge Condition }\end{array}$}} & \multirow{2}{*}{$\begin{array}{c}\text { Weight } \\
0,8313\end{array}$} & \multicolumn{2}{|r|}{ Subcriteria } & \multirow{2}{*}{$\begin{array}{c}\text { Weight } \\
0,0479\end{array}$} \\
\hline & & & A1 & River flow & \\
\hline & & & A2 & Safety Support Building & 0,0360 \\
\hline & & & $\mathbf{A 3}$ & Fondation & 0,2524 \\
\hline & & & A4 & Pier & 0,1086 \\
\hline & & & A5 & Girder System & 0,1281 \\
\hline & & & A6 & Parapet & 0,0597 \\
\hline & & & A7 & Floor System & 0,0992 \\
\hline & & & A8 & Expansion Joint & 0,0717 \\
\hline & & & A9 & Other Property & 0,0278 \\
\hline
\end{tabular}

Decision matrix in TOPSIS is obtained by inserting the bridge damage condition and average daily traffic. And than be calculated the distance between alternatives and positive ideal solution and negative ideal solution. Priority of bridge maintenance is obtained from the order of preference value between the positive ideal solution and negative ideal solution.

\section{Conclusion}

From 11 bridges considered in this study, Maris Bridge has the highest priority determined in 3 different methods. AHP and TOPSIS methods show Ringin Semar Bridge is the lowest priority to maintain. On the other hand, Fuzzy AHP was determined Balapan Bridge as the lowest order. The comparison of priority scale from the methods is shown in table 13.

The weight differences is due to the conversion of AHP rating into FAHP and the difference in the calculation with topsis. Conversion ratings on FAHP can make a criterion element have the same weight as zero so it will make a significant difference.

Seen in table 11, the weights for the ADT criterion and the complement are zero in FAHP method. This certainly gives a big influence compared to AHP which still gives weight to each element of the review. 
Differences are also seen in the priority ranking weighting of each bridge. Differences in the normalization of alternative quantification make the weight of each bridge on the method less than 1, whereas in the FAHP and TOPSIS methods almost all elements have more weight than 1 .

Table 13. Result Comparison

\begin{tabular}{cllllll}
\hline \multirow{2}{*}{$\begin{array}{c}\text { Priority } \\
\text { Number }\end{array}$} & \multicolumn{2}{c}{ AHP Method } & \multicolumn{2}{c}{ FAHP Method } & \multicolumn{2}{c}{ TOPSIS Method } \\
\cline { 2 - 7 } & Name of Bridge & Weight & Name of Bridge & Weight & Name of Bridge & Weight \\
\hline $\mathbf{1}$ & Maris & 0,2000 & Maris & 3,7249 & Maris & 0,7108 \\
$\mathbf{2}$ & Ngemplak & 0,1384 & Munggung & 2,8291 & Ngemplak & 0,6294 \\
$\mathbf{3}$ & Munggung & 0,1114 & Pasar Legi & 2,1956 & Munggung & 0,4045 \\
$\mathbf{4}$ & Komplang & 0,1041 & Nayu Ngemplak & 2,1334 & Komplang & 0,4016 \\
$\mathbf{5}$ & Pasar Legi & 0,0834 & Setabelan & 2,0931 & Rejosari & 0,3417 \\
$\mathbf{6}$ & Rejosari & 0,0735 & Komplang & 1,7860 & Pasar Legi & 0,3173 \\
$\mathbf{7}$ & Nayu Ngemplak & 0,0728 & Rejosari & 1,6519 & Setabelan & 0,2574 \\
$\mathbf{8}$ & Setabelan & 0,0638 & Ngemplak & 1,5549 & Nayu Ngemplak & 0,2551 \\
$\mathbf{9}$ & Ngebrusan & 0,0553 & Ringin Semar & 1,3229 & Ngebrusan & 0,2146 \\
$\mathbf{1 0}$ & Balapan & 0,0488 & Ngebrusan & 1,2636 & Balapan & 0,1974 \\
$\mathbf{1 1}$ & Ringin Semar & 0,0485 & Balapan & 0,9089 & Ringin Semar & 0,1945 \\
\hline
\end{tabular}

\section{References}

[1] Chang,D.Y.,1996, Applications of The Extent Analysis Method on Fuzzy AHP. European Journal of Operational Research, 95(3),649-655.

[2] Fajriyah, Ainun 2016 Implementasi Metode TOPSIS pada Sistem Pendukung Keputusan Seleksi Calon Tenaga Kerja di PT. Asry Amanah Timur Technical Information FMIPA Universitas Sebelas Maret Surakarta

[3] Fitriyanto A 2016 Sistem Penentuan Prioritas Pemeliharaan Bangunan Gedung Negara di Kabupaten Sragen (Studi Kasus Bangunan Gedung Sragen Technopark) Thesis Civil Engineering Universitas Sebelas Maret Surakarta

[4] Henderi, Norhikmah, Rumini 2013 Metode Fuzzy AHP dan AHP dalam Penerapan Sistem Pendukung Keputusan STMIK AMIKOM Yogyakarta 9

[5] Huang Y. H 2012. A Model for Concurrent Maintenance Of Bridge Elements. Automation in Construction 21 pages 74-80. Univ.of Science and Technology. Taiwan

[6] Hwang, C.L., \& Yoon, K. (1981), Multiple attributes decision-making methods and applications. Springer, Berlin.

[7] Junaidi et al 2006. Proceeding seminar on national management technology .Priority handling of road improvement project on segments roads in kabupaten kapuas by the method of ahp .Technology institute of ten november

[8] Kabir, G., Hasin, M.A.A. (2012). Comparative Analysis of TOPSIS and Fuzzy TOPSIS for the Evaluation of Travel Website Service Quality. International Journal for Quality Research, 6(3), 169-185

[9] Kementerian Pekerjaan Umum 2015 Informasi Statistik Infrastruktur Pekerjaan Umum dan Perumahan Rakyat PUSDATIN [2] Nurdin A, Kristiawan SA, Handayani D 2017 JP:Conf. Series. 795012070 
[10] Kilang C 2016 Evaluasi Kerusakan dan Prioritas Pemeliharaan (Studi Kasus di Kabupaten Sragen) Thesis Civil Engineering Universitas Sebelas Maret Surakarta

[11] Saaty TL 1988 What Is the Analytic Hierarchy Process. Berlin: Conference Paper, Mathematical Models for Decision Support. Vol 01, No 48

[12] Saaty TL 2008 Decision Making with the Analytical Hierarchy Process. Pitsburgh: International Journal Science Services. Vol 1, No 1:83-97

[13] Stratt RW 2010 Bridge Management a System Approach for Decision Making. Brussel: School of Doctoral Studies (European Union) Journal. Vol 11,No 4:67-108. 